\title{
A Homeowner's Guide to the Living Shoreline Permit Exemption Part 2: United States Army Corps of Engineers ${ }^{1}$
}

\author{
Savanna Barry, Sara Martin, and Eric Sparks²
}

\section{Background}

"Living shoreline" is a catch-all phrase that describes a riparian area managed with restoration techniques that use natural material such as oyster reef, mangroves, and marsh grasses to stabilize the area, prevent erosion, and protect property. Living shorelines typically involve construction or placement of materials within navigable waters of the United States. Therefore, the US Army Corps of Engineers (also known as the Corps) regulates the installation of living shorelines through a permitting process. This process ensures that project activities do not conflict with the public interest and defines actions that must be taken when a project is expected to have negative impacts. In the interest of streamlining the approval process for environmentally beneficial projects such as living shorelines, the Corps has created a permit process that operates like an exemption for small-scale living shoreline projects that meet certain criteria (see: http://edis.ifas.ufl.edu/sg155). The Corps process is similar but not identical to the Florida statewide exemption available through the Florida Department of Environmental Protection (DEP).

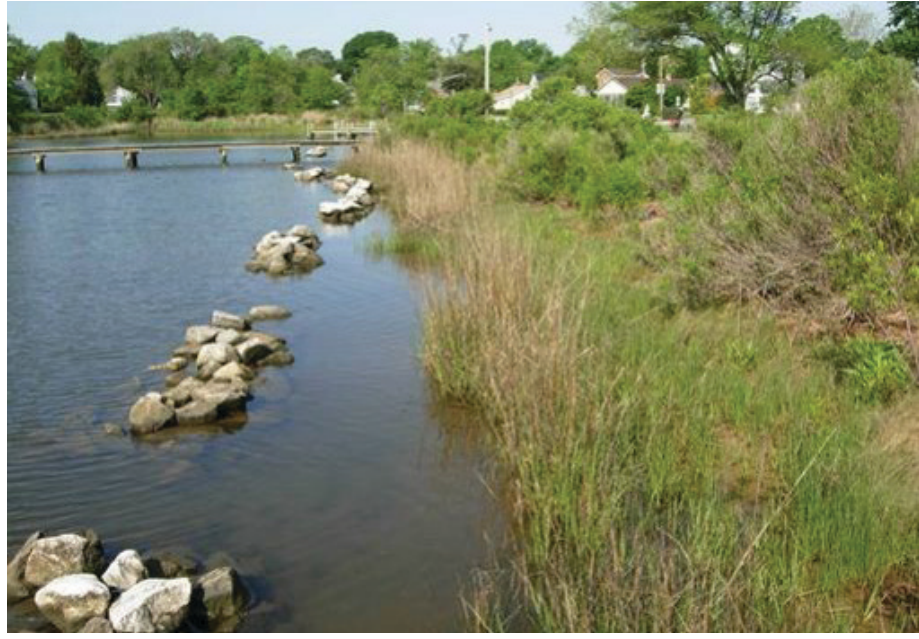

Credit: NOAA

Part 1 of this guide covers the DEP permit exemption and Submerged Lands Authorization process. If you have already navigated the DEP application process and received an official Verification of Exemption letter, Submerged Lands Authorization and if your DEP office also issued you a federal permit, then no further action is required before proceeding with your living shoreline project. However, if you did not receive a federal (Corps) permit through DEP, which is typically the case, then you must submit a separate permit application to the Corps.

1. This document is SG189, one of a series of the Florida Sea Grant College Program, UF/IFAS Extension. Original publication date March 2019. Visit the EDIS website at https://edis.ifas.ufl.edu for the currently supported version of this publication.

2. Savanna Barry, Florida Sea Grant agent, Nature Coast Biological Station; Sara Martin, Mississippi State University Extension, Coastal Research and Education Center; and Eric Sparks, Mississippi State University Extension, Coastal Research and Education Center; UF/IFAS Extension, Gainesville, FL 32611.

The Institute of Food and Agricultural Sciences (IFAS) is an Equal Opportunity Institution authorized to provide research, educational information and other services only to individuals and institutions that function with non-discrimination with respect to race, creed, color, religion, age, disability, sex, sexual orientation, marital status, national origin, political opinions or affiliations. For more information on obtaining other UF/IFAS Extension publications, contact your county's UF/IFAS Extension office. 
You probably already have all of the required information at your fingertips. The Corps permit application is short and free to submit, and it requires information very similar to that requested by DEP. Remember, Corps staff at your regional regulatory office are willing to meet with you on site or talk with you over the phone about your project during a "pre-application" meeting.

This guide provides example text for each application section that covers all of the bases but is still no longer than a paragraph for each section. You can adapt the example text to your needs. Site drawings can be hand drawn or easily produced using widely available software that you probably already have on your computer. As long as you have all the information and drawings handy, completing and submitting the form should take roughly 30 minutes. As stated above, this information is very similar to that requested by DEP, and thus there will be overlap between the information below and the information provided in Part 1 of this guide.

\section{What This Guide Covers}

This guide is a companion to the document A Homeowner's Guide to the Living Shoreline Permit Exemption Part 1: Florida Department of Environmental Protection. Consult Part 1 to learn about how to apply for the living shoreline permit exemption and Submerged Lands Authorization available through DEP. This guide (Part 2) covers the federal permit application managed by the Corps, a step which may not be necessary if the DEP issued both a federal and state permit for your project.

In Florida, permit applications are managed by the Jacksonville District of the Corps through a series of regional offices. Visit https://www.saj.usace.army.mil/Missions/ Regulatory/Office-Locations/ for a map of the counties in Florida covered by each regional office. You will need to complete the ENG FORM 4345 linked below. Complete it electronically or by hand and submit it by mail or email to the contacts listed on the regional offices web-page along with the required project drawings. There is no fee to submit the form. This guide will help you complete and submit the form correctly.

Steps to complete the Corps' permit application form are presented below, in a page-by-page fashion. You may also find value in the application instructions and checklist available as a PDF from the USACE at https://www.saj. usace.army.mil/Portals/44/docs/regulatory/sourcebook/ permitting/forms/Checklists/Checklist_ENG4345fillable. pdf.
The glossary provides definitions for several key terms you will need to understand when preparing your application.

\section{After You Submit}

Processing and approval of a permit application to the Corps typically takes about 60 days. If you fail to include any of the necessary information, a Corps officer will contact you with a request to provide the information or elaborate on certain aspects of the project. Failure to provide all of the necessary information may result in delays to your project approval.

\section{PDF Form}

The permit application form (ENG FORM 4345) can be downloaded by clicking the "Application Form" link at https://www.usace.army.mil/Missions/Civil-Works/ Regulatory-Program-and-Permits/Obtain-a-Permit/. You may fill out this form electronically, or you may print it and complete it by hand. The steps below will guide you through each page of the form. The final section shows examples of the vicinity map and drawings you are required to submit.

Page 1: On this page, you will need to provide general information such as your contact information, information about your property (location, tax parcel ID, and GPS coordinates), and (optional) the contact information of your agent, if any, and your signature authorizing the agent. Usually, the agent would be a contractor you are working with, but it is likely you will not have an agent if you plan to complete the project yourself.

Some specific tips and points to consider for Page 1:

- You can designate any project name or title that you wish

- The name of the waterbody should be name of the estuary, bay, river, stream, marsh, or creek where you will build your living shoreline project.

- You can locate the coordinates for your property using free tools such as Google Earth ${ }^{\oplus}$ or https://www.latlong. net/. Important: When entering coordinates for your project, make sure you provide them in the requested format (DD = decimal degrees). If the tool you use to locate the coordinates does not provide them in DD format, then you can use a free online coordinate converter such as http://www.earthpoint.us/Convert.aspx.

- Find your tax parcel ID number in any of several ways: 
Page 2: On this page, you must provide driving directions to your project site starting from a known landmark, such as an interstate exit, nearby town or city, or major highway intersection. You must also provide information about the project, including the nature of activity and project purpose. It is important that you are thorough and provide enough information for the Corps to assess whether or not your activity is allowable. Incomplete information in any of the sections on this or other pages will result in delays. You may append as many extra sheets as you need, with the block number of the question noted at the top of the extra sheet. If you first completed the Request for Verification of Exemption form for DEP, you will be able to re-use much of the descriptive text you already gathered.

Some specific tips and guidance for Page 2:

- See below for examples of nature of activity descriptions for three different scenarios: planting only, breakwater/ sill only, and breakwater/sill with planting. Feel free to adapt the example text below for your own use. Note: the figures given in the text below are only examples. You should consult with a local expert to determine the appropriate plant species, oyster reef heights, and materials to use in your project. Useful resources can be found at www. floridalivingshorelines.com, www.flseagrant.org, or your local UF/IFAS Extension office.

\section{Example Text:}

Plantings only-I plan to install native marsh vegetation along the shoreline of my backyard (100 linear feet). My property, located in Nature Bay, Florida, has been experiencing erosion over the past few years, likely because of seawalls on either side of my property. In order to slow and reverse this erosion, I will obtain smooth cord grass (Spartina alterniflora) from a local nursery and plant it in the intertidal zone along the shoreline. I will plant clumps of plants on 2-foot centers along a 10-foot-wide section of shoreline ( 5 rows of plants that will extend no more than 10 feet waterward of the mean high-water line). Planting will occur at low tide over the course of 2 to 3 days. Plants will be monitored for survival, and any plants that die within the first three months may be replaced with fresh specimens (also obtained from a nursery). All exotic/ vegetation will be removed from the site prior to project activities. No fill will be added other than soil imported with nursery grown transplants.

Breakwater/sill only-I plan to install an oyster reef breakwater in front of my property (90 linear feet) in Nature Bay, Florida, to protect my shoreline from further erosion. There are seawalls on either side of my property. I will deploy oyster shell contained within heavy-duty plastic mesh bags or gabions (approx. 4 to 5 gal. of shell per bag/ gabion). The bags/gabions will be deployed in the intertidal zone with the waterward toe occurring no more than 10 feet seaward of the mean high-water line. Bags/gabions will be stacked on top of each other in alternating orientations in order to achieve a height of 2 feet, allowing them to reach the ideal zone for oyster recruitment and growth. Bags will be deployed at low tide over the course of 1 to 2 weeks. The breakwater will not encroach upon and will not be placed anywhere within 3 feet of any submerged or emergent vegetation. There are no seagrass meadows in the vicinity of my project. seagrass meadows. The waterward toe of the breakwater will not be placed more than 10 feet seaward of the mean high tide line. We will use stable, natural materials (bagged oyster shell/oyster shell contained in gabions) to construct the breakwater and the bags/gabions will be secured using rebar stakes. Shell will be contained in heavy duty plastic mesh bags or metal gabions with 2.5-inch openings. Shell material will be sourced from Nature Bay Shell Recycling that has seasoned the shells outside in the sun for at least 6 months. Additionally, the breakwater will have a 6 -foot wide gap every 47 feet along the shoreline. Oyster shell bags will be deployed using hand carry methods and, thus, no equipment with the potential to damage the shoreline will be used.

Breakwater/sill and plantings-I plan to install a concrete dome breakwater in front of my property on Nature Bay, Florida, to protect my shoreline (300 linear feet) from further erosion. There are seawalls on either side of my property. Concrete domes will be deployed by professional contractors in the intertidal zone, with the waterward toe of the concrete domes occurring no more than 10 feet seaward of the mean high-water line. Concrete domes will be approximately 1.5 feet tall, placing a high percentage of the concrete dome surface area within the ideal zone for oyster recruitment and growth. Concrete domes will be deployed continuously regardless of tidal stage using hand-carry/ float methods over the course of 1 week. After installation of concrete domes, the shoreline behind the breakwater will be planted with native vegetation to further reduce erosion and increase habitat value. I will obtain smooth cord grass (Spartina alterniflora) from a local nursery and plant clumps of plants on 2-foot centers behind the 10-footwide section of shoreline protected by the concrete domes ( 5 rows of plants that will extend no more than 10 feet waterward of the mean high tide line). Planting will occur at low tide over the course of 2 to 3 days. Plants will be monitored for survival, and any plants that die within the 
first three months may be replaced with fresh specimens (also obtained from a nursery). All exotic/invasive vegetation will be removed from the site prior to project activities. Plantings will extend no more than 10 feet seaward of the mean high tide line and the inner toe of the breakwater will likewise extend no further than this line. No fill will be added other than soil imported with nursery-grown transplants. The breakwater will not encroach upon and will not be placed anywhere within 3 feet of any existing submerged or emergent native vegetation. The coastal area behind my home is a mudflat, and there are no seagrass meadows within 0.5 mile of my home. The breakwater will be constructed of stable materials (concrete domes) and will be secured using fiberglass stakes. Rows of concrete domes will have 5 -foot-wide gaps every 70 feet along the shoreline. There will be four, 70-foot-long breakwaters with 5-foot gaps in between each. Concrete domes will be deployed by professional contractors using hand-carry and float methods, and, thus, no equipment with the potential to damage the shoreline will be used.

- See below for some example descriptions of project purpose. Feel free to adapt the example text below for your own use, but keep in mind that you should consult with an expert for help choosing the best method for you.

\section{Example text:}

Plantings only-This project aims to create/restore wetlands in order to benefit from the ecological functions. By installing native vegetation, this project will benefit the local ecosystem as well as my personal property.

Breakwater/sill only-The breakwater will be constructed in the intertidal zone in water deeper than mangroves and marsh grass can survive. The primary purpose of the project is to mitigate erosion along the shoreline adjacent to my property. The project will create habitat for oyster recruitment and overall will benefit the local ecosystem.

Breakwater/sill and plantings_-This project aims to create/ restore wetlands in order to benefit from the ecological functions. By installing native vegetation and oyster recruitment substrate, this project will benefit the local ecosystem.

- Unless you are installing plants only, you will need to fill out the dredge/fill material sections (blocks 20-23). In the eyes of the Corps, materials such as oyster bags, gabions, cinder blocks, and rocks are considered fill material. Therefore, you will need to fill out this section if your project incorporates oyster shells, concrete domes, gabions, coir logs, sand fill or other structural elements.
Feel free to adapt the example text below for your own use, but keep in mind that you should consult with an expert for help choosing the best method for you.

\section{Plantings only}

Block 20. There will not be any discharge associated with the project other than that imported with nursery-grown plants. Plants must be installed to mitigate erosion.

Block 21. N/A

Block 22. N/A; wetlands will be created, not filled in.

Block 23. Plantings will occur at low tide and cease when the tide covers the work area. There will not be any sediment releases or turbidity associated with planting at low tide because resuspension of sediments will be impossible without water present. Sediments loosened by digging holes for plants will be packed back into place immediately upon placing the plant in the hole.

\section{Breakwater/sill only}

Block 20. In order to mitigate erosional forces of waves and currents, it is necessary to deploy a breakwater/sill structure. I have selected bagged oyster shell as the appropriate material to place in front of my property to achieve erosion control.

Block 21. Type: bagged oyster shell; amount in cubic yards: $18.7^{\star}$

${ }^{*}$ Amount in cubic yards can be estimated by:

1.calculating the length of the project in feet, subtracting any mandatory gaps (90 feet minus 6 -foot gap $=84$ feet in this example);

2. estimating the height and width in feet ( 2 and 3 feet, respectively, in this example);

3. multiplying the three numbers together (length $\times$ width $\times$ height) to yield the volume in $\mathrm{ft}$ (504 $\mathrm{ft}$ in this example); and

4. dividing by 27 to yield the value in cubic yards $(18.7 \mathrm{cu}$ yd in this example).

Block 22. N/A; wetlands will be created, not filled in.

Block 23. The breakwater will be installed at low tide, and all activity will cease when the tide covers the work 
area. There will not be any sediment releases or turbidity associated with deploying oyster bags at low tide because resuspension of sediments will be impossible without water present at the site.

\section{Breakwater/sill and plantings}

Block 20. In order to mitigate erosional forces of waves and currents, it is necessary to deploy a breakwater structure with plants behind it. I have selected Spartina alterniflora and concrete domes as the appropriate material to place in front of my property to achieve erosion control.

Block 21. Type: concrete domes; amount in cubic yards: $40^{\star}$

${ }^{\star}$ See above for instructions on how to estimate cubic yards

Block 22. N/A; wetlands will be created, not filled in.

Block 23. Plantings will occur at low tide and cease when the tide covers the work area. There will not be any sediment releases or turbidity associated with planting at low tide because resuspension of sediments will be impossible without water present. Concrete domes will be deployed using hand-carry and/or float methods, and very limited resuspension of sediments will occur with this method (walking across the site). No heavy equipment or tools (other than a hammer to drive in a narrow fiberglass rod) will be used in this project. The disturbance to sediments at the site will be minimal.

Page 3: On this page, you must provide background information about any work that has already been completed (usually none for a living shoreline), contact information for neighboring properties, and any permits or authorizations you have already received. Finally, you need to sign and date the permit application. See https://www.saj. usace.army.mil/Missions/Regulatory/Office-Locations/ for information about where to submit your permit. Select the regional office that serves your county, and either email or mail the application and all attachments (see below) to the appropriate location.

Attachments: You must include 1) a vicinity map with enough detail to allow someone to find the project, 2) an overhead (plan) view and cross-section drawings of a) the present site condition and $b$ ) your project when you submit the PDF form. See below for examples of acceptable plan view and cross-section drawings.
The detailed set of drawings should depict both the current site conditions and the project in cross section and in overhead (plan) view. These drawings must show:

1) The location of the mean high-water and mean lowwater lines;

2) The linear distance along the shoreline covered by the project;

3) The linear distance the project will extend into the water, as measured from the mean high-water line;

4) Planned spots for placement of plants, breakwater/sill elements, and gaps in breakwaters with linear distances and/or heights noted;

\section{5) Existing structures;}

6) Any nearby habitats and the approximate location of the shoreline of neighboring properties.

You may produce these drawings yourself either by hand or using simple shape illustrations available in computer programs such as Microsoft PowerPoint. Drawings need not be to scale, as long as this is noted on the drawing. It may be helpful to include extra photographs of the site to aid in your explanation. Of course, you always have the option of hiring a contractor who will provide the drawings as part of the contract, but this is typically not necessary for simple projects. To give you an idea of the level of detail required, see the example cross section and plan view drawings below. We have provided an example for each of the three basic project types mentioned above: plantings only, breakwater/sill only, breakwater/sill and plantings.

\section{Vicinity Map}

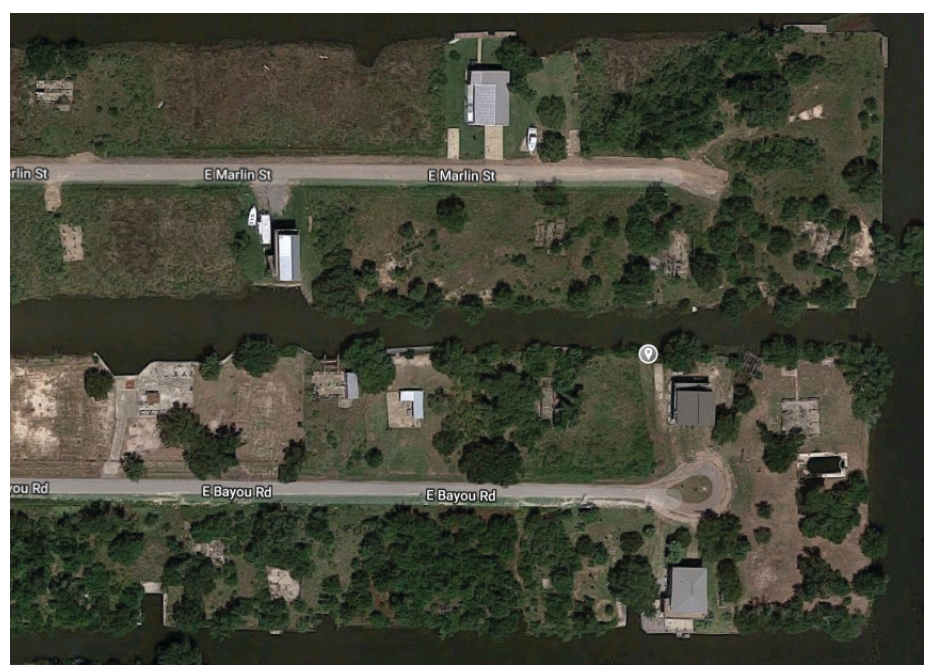




\section{Present Condition}
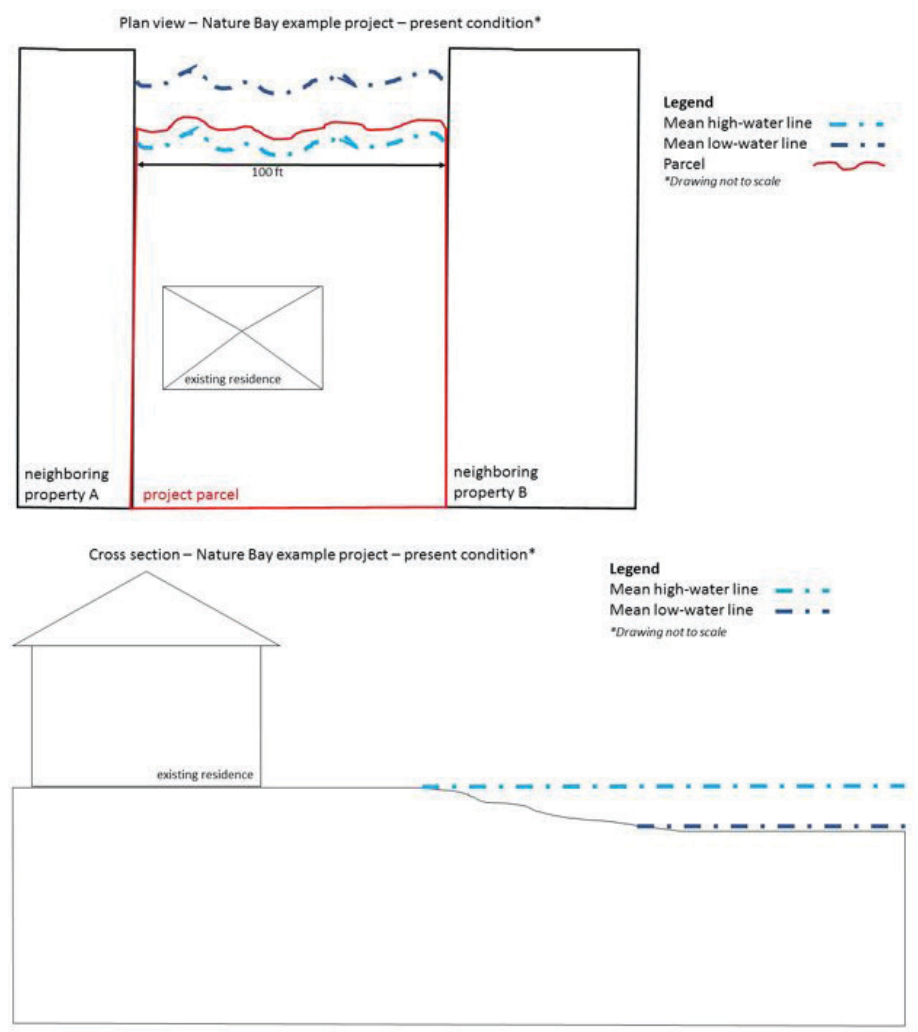

\section{Plantings Only}
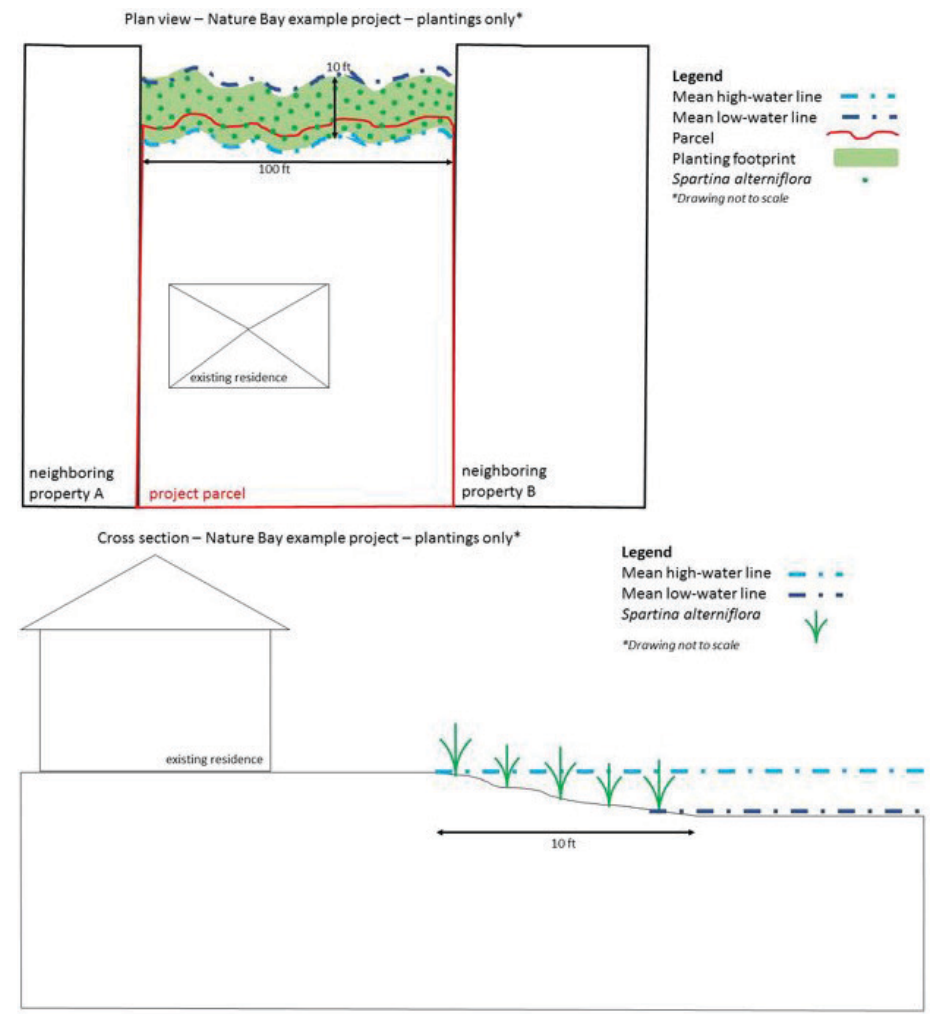

\section{Breakwater/Sill Only}

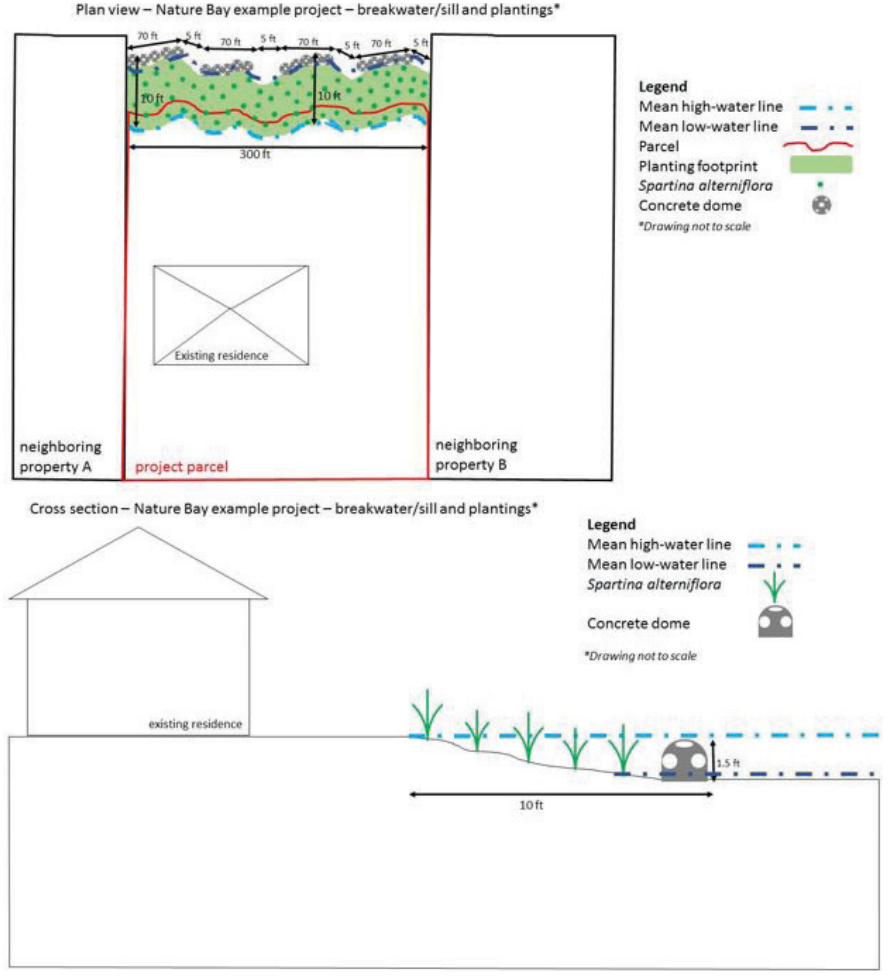

\section{Conclusion}

This guide covered the process for applying for a streamlined living shoreline permit from the US Army Corps of Engineers. We covered background information about living shoreline permits, provided sample text for several sections of the Corps application, and outlined the process for creating acceptable project drawings for small-scale projects. We gave instructions for submitting the permit application to the Corps. If you provided complete and correct information on the application, within 60 days you should receive confirmation that your project is approved. The Corps will send you a permit letter with attachments. The letter will notify you that your project has been approved and outline instructions for communicating with the Corps regarding construction activities. Be sure to thoroughly read the letter you receive, and make note of any additional permits or follow-up information you may need to provide. To avoid fines, fees, or other regulatory action, make sure you construct your project exactly as planned. If you find you need to make changes to your project, notify the Corps before you make them to verify the changes will not jeopardize your approval. 


\section{Helpful Resources}

Florida Sea Grant Living Shorelines: https://www.flseagrant. org/news/tag/living-shorelines/

Florida Living Shorelines Project Example Page: http:// floridalivingshorelines.com/florida-sampler/

Florida Living Shorelines Resource Database: http:// floridalivingshorelines.com/resources/

NOAA Understanding Living Shorelines: https://www. fisheries.noaa.gov/insight/understanding-living-shorelines

NOAA Climate Resilience Toolkit: https://toolkit.climate. gov/topics/coastal-flood-risk/coastal-erosion

NOAA Living Shorelines: https://www.habitatblueprint. noaa.gov/living-shorelines/

NOAA Tools for Planning: https://www.habitatblueprint.noaa.gov/living-shorelines/applying-science/ tools-for-planning/

NOAA Guidance and Training: https://www.habitatblueprint.noaa.gov/living-shorelines/applying-science/ guidance/

NOAA Consultations and Permits: https://www. habitatblueprint.noaa.gov/living-shorelines/ consultations-permitting/

StormSmartCoasts - Erosion Control Structures: http://ms.stormsmart.org/before/mitigation/ only-as-a-last-resort-flood-and-erosion-control-structures/

StormSmartCoasts - Non-structural Shore Protection: http://ms.stormsmart.org/before/mitigation/ non-structural-shore-protection/

Contact information for professionals working on living shorelines in your region can be found at http://floridalivingshorelines.com/contacts/ or your local UF/IFAS Extension Office.

\section{Glossary of Terms}

Breakwater-generally, a structure built to provide a barrier to or protection from waves. There are many definitions of the term "breakwater," but usually they are offshore structures designed to reduce incoming wave energy, resulting in calmer water between the shoreline and the structure. Oyster reef breakwaters are built at intertidal heights (submerged at high tide) out of materials conducive to colonization by oysters. In Florida, breakwaters built as part of small-scale living shorelines are only exempt from permitting if they are built no higher than the mean high-water line.

Clean oyster shell-Oyster shell used in living shorelines must be clean of disease and pests in order to be a safe material. There are several sources of clean oyster shell, including recycled shell and fossilized shell, from both non-profit and for-profit organizations. Recycled shell that comes from seafood restaurants must be cured outdoors in a sunny area in piles that are routinely turned for at least 6 months. This prevents the spread of oyster pests and disease. The DEP will usually request information about the specific source of the shell when reviewing an application for Verification of Exemption.

Coir logs-biodegradable logs made from coconut fiber often used in construction of sills in living shorelines.

Concrete dome-concrete forms in the shape of domes. This method of oyster reef construction uses molded, precast concrete forms designed to mimic the attributes of the natural three-dimensional structure of oyster reefs. In some cases, the concrete mixture is fortified with an additive to increase oyster recruitment. There are many commercially available forms.

Cross-section drawing - a depiction of your living shoreline project in cross-section, including information about the slope of the shoreline, approximate mean low-water and mean high-water locations, breakwater heights, spacing of plants, location of existing structures, etc.

Emergent vegetation-wetland plants that are rooted with stiff or firm stems, like cattails. Emergent vegetation usually stands above the water surface, but in some cases can be found submerged during occasional periods of high water. Lily pads and many marsh plants are considered emergent plants.

Erosion-process of sediment being carried away from an area. In coastal environments, the major driving processes of erosion are storms, flooding, wave action, sea level rise, and human activities (i.e., boating, seawall construction, development). Erosion is a natural process in coastal ecosystems, but it becomes an issue when homes and other infrastructure are threatened. 
Exotic/invasive species-exotic species are those that are not native to an ecosystem. Invasive species are those that are not native to an ecosystem and cause harm to native species and/or ecosystem functions. Examples of invasive plants in Florida's coastal environments include the invasive Brazilian pepper and Phragmites australis marsh grass. You can check to see if a plant is invasive at https://assessment. ifas.ufl.edu/assessments/.

Intertidal zone-the area that is above water at low tide and under water at high tide (in other words, the area between tide marks), commonly inhabited by oysters.

Gabion-a wire framework container that provides a structured foundation for shell material. Made of a material similar to chain-link fencing, gabions are filled with shells and ballast, then stacked and wired together to construct sturdy, three-dimensional structures.

Marsh vegetation-herbaceous (non-woody) plants that thrive in wetlands. A wetland is an area that is inundated or saturated by surface water or ground water at a frequency and a duration sufficient to support, under normal circumstances, a prevalence of vegetation typically adapted for life in saturated soils. Most living shorelines deal with the creation of low and middle marsh that are more frequently inundated by water than the upper marsh zone.

Mean high-water line (MHWL) - the line on a chart or map that represents the intersection of the land with the water surface at the elevation of mean high water (the average of all the high water heights observed over the period of time defined by the National Tidal Datum Epoch). Homeowners can roughly estimate the MHWL using physical markers like stakes or flags placed at high tide over a period of weeks, or by observing and marking the location of at the tidal wrack lines (line formed by debris washing up at high tide), or by looking at aerial photos. DEP suggests erring on the upland side instead of the waterward side when approximating the MHWL. The MHWL can also be determined by a licensed surveyor.

Mean low-water line (MLWL) - the line on a chart or map that represents the intersection of the land with the water surface at the elevation of mean low water (the average of all the low water heights observed in the period of time defined by the National Tidal Datum Epoch). Homeowners can roughly estimate the MLWL using physical markers like stakes or flags placed at low tide over a period of weeks or by observing aerial photos. The MLWL can also be determined by a licensed surveyor.
National Tidal Datum Epoch-the specific 19-year period adopted by the National Ocean Service as the official time segment over which tide observations are taken and reduced to obtain mean values (e.g., mean lower low water, etc.) for tidal datums. It is necessary to standardize mean tide level in this way because of periodic and apparent trends in sea level.

Native vegetation - plants that occur naturally in an area.

Ordinary high-water line (OHWL) - the analogue of the mean high-water line for freshwater bodies such as rivers, streams, and lakes. The OHWL is typically determined by using the best evidence available, including water marks, soil and vegetation indicators, and historical aerial photos.

Oyster-recruitment substrate-structure such as shell or concrete deployed in the intertidal zone of the coast for the purpose of increasing oyster attachment opportunities.

Plan-view drawing - a depiction of your living shoreline project from an overhead perspective, including information about the approximate mean low-water and mean high-water lines, breakwater/sill placement and spacing, spacing of plants, location of existing structures, location of parcel boundaries, etc.

Sill-material deployed at the base (toe) of a vegetated zone for the purpose of reinforcing and protecting the area from moderate energy waves and currents. Sills can be constructed out of materials such as shell, concrete, or coconut fiber logs. Sills differ from breakwaters in that they are constructed directly adjacent to the vegetated area.

Submerged aquatic vegetation (SAV) - Grasses that grow to-but not above - the surface of shallow water. This includes seagrasses and freshwater aquatic grasses.

Turbidity - the measure of suspended solids, which influences water clarity. Murky water has high turbidity.

Waterward toe- - the bottom-most portion of the offshore side of a structure such as a sill or breakwater. 


\section{Sources}

Florida Administrative Code 62-330.051(12)(e)

Florida Master Naturalist Program-Coastal Systems

Manual

Florida Master Naturalist Program-Coastal Shoreline Restoration Manual

https://aquaplant.tamu.edu/plant-identification/ category-emergent-plants/

https://chesapeakebay.noaa.gov/ submerged-aquatic-vegetation/ submerged-aquatic-vegetation

https://shoreline.noaa.gov/glossary.html

https://toolkit.climate.gov/topics/coastal-flood-risk/ coastal-erosion 